\title{
THE ROLE OF UNIVERSITY-BASED INCUBATORS IN SOCIAL ENTREPRENEURSHIP'S DEVELOPMENT: THE CAPABILITY APPROACH AS AN EVALUATIVE FRAMEWORK
}

\author{
Matahari Farransahat $^{1 *}$, Risa Bhinekawati ${ }^{2}$, and Evelyn Hendriana ${ }^{3}$ \\ ${ }^{1}$ Faculty of Social and Political Science, Universitas Gadjah Mada, Sleman, 55281, Indonesia \\ ${ }^{2}$ Sekolah Tinggi Ekonomi dan Perbankan Islam Mr Sjafruddin Prawiranegara. Jakarta, 13220, Indonesia \\ ${ }^{3}$ Binus Business School Master Program, Bina Nusantara University, Jakarta, 11480, Indonesia
}

\begin{abstract}
Introduction/Main Objectives: This study evaluates the role of a large university in developing the social entrepreneurship capabilities of its students and fresh graduates through its business incubator; and investigates why tenants choose to be or not to be social entrepreneurs after their incubation process. Background Problems: There are many discussions about university-based incubators for developing entrepreneurship, but the actual mechanism of how these incubators develop social entrepreneurs is still unknown. Novelty: This research explores the development of social entrepreneurship through the university-based incubator program. Hence, it can be used to provide best practices for the program, especially for developing the tenants' capacity. Research Methods: This study applies a case study approach and adopts Amartya Sen's capability approach as an evaluative framework. The CHub UGM was chosen as a case since it was selected as a good example of a social entrepreneurship incubator by the British Council. This research used three sources of evidence: documents, interviews, and focus group discussions to collect information from 14 of the incubator's tenants. Finding/Results: The results reveal that the incubator serves as a hub for the resources that enhance the tenants' personal conversion factors and their performance as agents for change. Subsequently, the incubator improves the tenants' social entrepreneurship capabilities set; however, it is up to the tenants to choose whether they want to continue as social entrepreneurs or work in other roles as their functioning. Conclusion: This study illuminates the linkages among the concepts of the capability approach, the university-based incubator and social entrepreneurship. It reveals that the university-based incubator serves as a hub for the resources that enhance the tenants' personal conversion factors; thereby they can be effective social entrepreneurs.
\end{abstract}

\section{ARTICLE INFO}

Article information:

Received 4 April 2021.

Received in revised

version 7 August 2021.

Accepted 4 September

2021

Keywords:

capability approach, personal conversion factors, C-Hub Gadjah Mada University, social entrepreneurship, university-based business incubator

JEL Code:

I23, Z13, 015

\footnotetext{
* Corresponding Author at Department of Social Development \& Welfare, Faculty of Social and Political Science, Universitas Gadjah Mada, Karang Malang, Caturtunggal, Depok, Sleman, Yogyakarta 55281, Indonesia. E-mail address: matahari.farransahat@ugm.ac.id (author\#1), risa.bhinekawati@stebankislam.ac.id (author\#2), evelyn.hendriana@binus.ac.id (author\#3)
} 


\section{INTRODUCTION}

Social entrepreneurship has grown its importance in advancing solutions to social problems and in its contribution to the Sustainable Development Goals (SDGs) (Luc, 2020). In Indonesia, social enterprises contribute to the country's SDGs through inclusive and creative business practices in the areas of energy, education, and nutritious food (British Council, 2018). By 2018, the number of social enterprises reached 342,025 units, which contributed around $1.91 \%$ of Indonesia's GDP (USD 19.4 billion), absorbing over seven million employees or $3.73 \%$ of Indonesia's workforce (British Council, 2018). The growth in employment by social enterprises was $42 \%$, compared to the growth rate of the average micro, small and medium enterprises (MSME), which was 5.9\% from 2016 to 2017 (BAPPENAS, 2016). Most of the social enterprises can be classified as micro and small enterprises, where $46 \%$ of their leaders are aged between 25 and 34 years old (British Council, 2018). However, in general, social enterprises experience various challenges at every stage of their development, especially in the matter of their management, finding the right business model, getting partners, and access to finance (Bhardwaj \& Ruslim, 2018). Social enterprises need the support of enablers, including higher education institutions, to improve their capacity to attract funding and in enhancing their business skills and technical skills (UNDP, 2017). Universities have been catalysts for entrepreneurship's capital development and knowledge spillovers (Audretsch, 2017) which can be done through business incubators for their students and graduates (Bennet et al., 2017). The business incubator is an organization which is established to develop new ventures by providing them with services, facilities, knowledge, and support (Bruneel et al. 2012; Mas-Verdú et al., 2015). To encourage entrepreneurship's development in higher education, the Government of Indonesia has issued various policies and regulations on the schemes for establishing business incubators in universities (Ristekdikti, 2017).

Although the topic of university-based incubators has been widely discussed, academic literature on the actual mechanisms of how these incubators develop social entrepreneurs, and why tenants choose other professions rather than being social entrepreneurs after being incubated, is still lacking. A recent literature review by Ayatse et al. (2017) reveals that business incubators contribute to business survival and growth, and they specifically suggest further research into how university-based incubators improve the sustainability of new business ventures. In the area of social entrepreneurship, Weaver (2018) argues that institutions can develop the capabilities of social enterprises and recommends further research to identify the actual mechanisms for social entrepreneurship's capability development. Furthermore, Lasrado et al. (2016) found that university-based incubators have been successful in nurturing entrepreneurs; however they did not explore tenants' decisions whether to continue as entrepreneurs or decide to enter another profession.

Based on the above research gaps, this research has two objectives: First, to investigate the role of a university-based incubator in developing social entrepreneurship. Second, to explore why tenants decide to be, or not to be, social entrepreneurs after being incubated.

As the case study, we use Gadjah Mada University (UGM), one of the largest universities in Indonesia with 56,263 students in 2020. UGM established the Creative-Hub (C-Hub) in 2018 to contribute to the country's SDGs by enabling students and fresh graduates to become social entrepreneurs. Until February 2020, C-Hub had conducted three recruitment drives for potential 
social entrepreneurs, resulting in the selection of 39 tenants, of these $49 \%$ of them perform well, $13 \%$ are in stagnant positions, and $38 \%$ of them decided to do other things instead of being social entrepreneurs. This varied performance has triggered C-Hub's management to evaluate the role of C-Hub in developing social entrepreneurship, and to explore the tenants' choices after being incubated.

As an evaluative framework, the capability approach, which has been pioneered by Amartya Sen (1992, 1999), is used in this case study. The capability approach concerns people's freedom and opportunities to achieve their function or what they value doing and being (Sen, 2009). It can be applied for evaluating whether an institution's policies or initiatives create improvements in the lives of the target groups (Robeyns, 2017).

\section{LITERATURE REVIEW}

\section{Capability Approach as an Evaluative Framework}

The capability approach, introduced by Amartya Sen $(1992,1999)$ asserts that capabilities are combinations for the possibilities and opportunities of functionings that can be achieved by a person. They represent a person's freedom to lead his/her life based on the possibilities that she/he has (Sen, 1992). The capability approach can evaluate whether a policy or program can improve a person's capabilities and functions; and to examine whether the policy or program can strengthen certain capabilities that enhance the possibilities of the person's function (Robeyns, 2017). As an evaluative framework, the capability approach is considered to be suitable to be applied in this study as it attempts to investigate the role of a university-based incubator in developing social entrepreneurship, and to explore why tenants decide to be, or not to be, social entrepreneurs after being incubated.
The main concepts of the capability approach used in this study include, first, "capabilities and functions" (Robeyns, 2017) to explain how an incubator transforms social entrepreneurship capabilities into social entrepreneurship performance as functions; second, "resources" (Robeyns, 2017) to explain the role of an incubator as the university's hub which supplies the resources given to the tenants; third, "agency or an agent" (Sen, 1999) to explain the role of social entrepreneurs as agents for change; fourth, "personal conversion factors" (Robeyns, 2017) to explain the capability of tenants to convert resources into functions; and fifth, "choice" (Robeyns, 2017) to explain the freedom the tenants have to decide whether they want to be, or not to be, social entrepreneurs as their function in life after the process of incubation. The linkages among the concepts of the capability approach, social entrepreneurship and the university's incubator are discussed below.

\section{Incubator as Hub of Resources that Enhance Tenants' Personal Conversion Factors}

According to Robeyns (2017), resources are capability inputs, and they can be in the form of measurable resources such as money, or other resources such as skills and education. Different people can achieve different levels of well-being or functioning, depending on their personal conversion factors, and the influence of the social and environmental resources available to them (Robeyns, 2017). The ability of a person to convert resources into functions depends on the personal conversion factors which are owned by the individual, including his/her physical stamina, skills and intelligence (Robeyns, 2017).

In the context of a business incubator, it can be argued that the incubator functions as the hub for the resources that enhance the startups' or tenants' personal conversion factors. Experts 
came to a similar conclusion, that business incubators are established to provide support for startups or tenants, in the form of infrastructure, services and resources (Bruneel et al., 2012; MasVerdú et al., 2015). An office space, meeting areas and internet access are common forms of infrastructure support; while for services, an incubator usually conducts business training, mentoring, coaching, and consultations, as well as providing funding and networking support (Lasrado et al., 2016; Albort-Morant \& Oghazi, 2016). Hence, it can be concluded that an incubator serves as a supplier of the resources that enhance the tenants' personal conversion factors, by facilitating them with business skills and knowledge, a supportive working environment, access to funding, and networking opportunities.

Resources provided by an incubator are expected to enhance the tenants' personal conversion factors, which will improve their capabilities in converting resources into functioning ideas. To measure the tenants' performance, Ayatse et al. (2017) and Voisey et al. (2006) used both non-financial and financial measurements, and soft and hard outcomes. The soft outcomes reflect qualitative measures such as improvements in productivity, confidence, business and management skills, communications, and networking abilities. Hard outcomes are measured through increases in sales, revenue growth, investment raised, numbers of employees, and numbers of people in the social network (Voisey et al., 2006; Ayatse et al., 2017). Hence, the success of an incubator can be measured by the performance of its tenants during and after the incubation process. With the support of an incubator, it is expected that the tenants' personal conversion factors will improve, thus, their ability to convert resources into actual businesses will also increase

\section{Tenants as Potential Social Entrepreneurs or Agents of Change}

According to Amartya Sen, an agent is "someone who acts and brings about change and whose achievements can be judged in terms of his/her own values and objectives" (Sen, 1999, p.19), and the "agency" is "what a person is free to do and achieve in pursuit of whatever goals or values he or she regards as important." (Sen, 1985, p.203). The role of an agency is very important as the capability approach deals with human beings as key players in the concept of development (Sen, 1990).

The concept of agency is relevant to explain the role of social entrepreneurs as agents for change. As proposed by Bacq and Janssen (2011), social entrepreneurs have some similar behavioral characteristics to those of entrepreneurs, including the ability to find opportunities, the determination to innovate, the ability to take risks and high determination for nurturing and growing their business. The main difference they find in the characteristics of social entrepreneurs is the demonstration of social value in their business initiatives. Individuals possessing these characteristics are more inclined to start their own social enterprise venture than working for a multinational enterprise or commercial small and medium enterprise (Bacq \& Janssen, 2011). Similarly, Shaw and Carter (2007) found that social entrepreneurs in the UK are motivated to become agents for social change by dealing with social issues. They argue that a social entrepreneur's main concern, when establishing a social venture, is to address the social issues within society, such as services to the disabled, poor access to housing facilities to low-class community, high unemployment rates, and so on (Shaw \& Carter, 2007). Nga and Shamuganathan (2010) also found that the characteristics of agents for change are reflected through the 
attitudes of social entrepreneurs who are more concerned about the social problems and the need to improve society's quality of life. Due to their concerns about improving people's quality of life and solving the social problems, social entrepreneurs are perceived as individuals who have a social vision and the ability to develop sustainable businesses with good financial returns that cover the social value's creation (Nga \& Shamuganathan, 2010).

Furthermore, Dees (1998) recognizes that social entrepreneurs are agents for change as they have social value added, rather than just private value added, as their mission; social entrepreneurs are also innovative and adaptive in pursuing ways to achieve their mission with a high sense of responsibility about achieving their outcomes and servicing their constituents. Moreover, as agents for change, social entrepreneurs transform the ways in which institutions work to promote solutions for social issues like poverty, environmental degradation, the lack of education, and health issues to improve the wellbeing for many (Bornstein \& Davis, 2010). In sum, social entrepreneurs are leaders who strive to make a difference by achieving social change and bringing sustainable social and economic benefits to the people they serve (Fowler, 2000; Prabhu, 1999).

\section{Social Entrepreneurship Capabilities and Functionings}

The key concepts of the capability approach are capabilities and functions. According to Robeyns (2017, p.38), capabilities are "what people are able to do" and functions are "the corresponding achievements." The functions are "the various things a person may value doing and being" (Sen, 1999, p.75) or important situations and activities recognized as a person (Alkire, 2002). In other words, a function is an achievement, while a capability is the ability to achieve what a person values as being important (Robeyns, 2017). Hence, when an institution intends to conduct any development programs, they must intend to expand the capabilities of the people involved, so they can achieve their functions and get access to resources and make choices about the functions that matter to them (Alkire, 2005).

The concept of capabilities and functions are then applied to the role of an incubator to expand social entrepreneurship's capabilities and functions. In this case, Urban (2008) posits that social entrepreneurship's competence/skills are a set of skills, knowledge and resources that differentiate a social entrepreneur from his/her competitors. Urban (2008) argues that entrepreneurship education may influence one's intention and behavior to become an entrepreneur in the future. To become a social entrepreneur, a person must be equipped with some competency and skills through social entrepreneurship education, due to the unique characteristics of social entrepreneurship's activities (Howorth et al., 2012; Pache \& Chowdhury, 2012). Furthermore, Urban (2008) reported that various managerial and entrepreneurial competences/ skills were essential to build a successful social entrepreneurship venture. The acquisition of business and market-related skills is essential for a social entrepreneur to enable him/her to solve social problems and improve other people's quality of life (Salamzadeh et al., 2013). The role of an incubator is then to expand people's social entrepreneurship capabilities and encourage them to function as social entrepreneurs, by providing them with resources including role models, training, coaching and mentoring programs, access to funding and networks, as well as office infrastructure (Salamzadeh et al., 2013).

With this support, tenants are expected to have the capabilities to create a competitive advantage for their business. According to Sinthupundaja et al. (2020), there are four 
dimensions of management capabilities in social entrepreneurship, including mission-driven, stakeholder, cross-sector collaboration, and environmental management capabilities. The mission-driven management capability guides social entrepreneurs to carry out their missions consistently, related to the decision-making in the business model. The stakeholder-management capability provides support in responding to the main stakeholders such as partners, customers, and shareholders. The management capabilities of cross-sector collaborations connect the barriers that usually occur in the private, public, and nonprofit sectors to reconcile the desired goals. Environmental management capabilities help social entrepreneurs by connecting their businesses to natural resources and resolving environmental issues (Sinthupundaja, et al., 2020). Accordingly, it can be concluded that social entrepreneurship's capabilities and functions can be expanded by the presence of an incubator.

\section{Tenant's Choice in Becoming Social Entrepreneurs or Other Functions}

Robeyns (2017) argues capabilities and functions are influenced by resources and choices. She proposes that the available resources influence a person's ability to convert resources into functions, and the act of choice is necessary to move from capabilities to functions (Robeyns, 2017). Hence, any efforts to develop should be given access to valuable resources, so they can enhance their capabilities and freedoms in choosing "valuable beings and doings" or functions (Robeyns, 2006, p.117). Therefore, the capability approach can be applied for the evaluation of policy implementation, to investigate people's choices from the "menus" of the different possibilities to achieve the functions (Alkire, 2002, p. 123; Robeyns, 2005, p.101).
As people make choices based on their ideas of well-being, people with similar capabilities may not have similar functions (Robeyns, 2005). Referring to the expected utility theory, every individual is a rational decision-maker. This theory assumes that the individual is completely informed, fully aware of all the available alternatives, and able to accurately predict the expected utility of each alternative (Edwards, 1954; Schoemaker, 1982). As a rational person, he or she holds a certain belief about the expected outcome and the probable state, which is measured by the probability of the occurrence. $\mathrm{He} / \mathrm{she}$ calculates the expected utility of each alternative based on the utility or value of the outcome and the probability of the occurrence of the situation (Briggs, 2019). As a result, he/she will choose the best alternative that maximizes his/her utility. While the original expected utility theory assumes an individual to be self-centered (Edwards, 1954), Sen (1977) argues that this theory does not necessarily requires one's preference to be self-interest. His proposition is based on the psychological theory, where an individual may choose to have a narrow selfinterest, a broad self-interest that may be expressed through his/her sympathy toward others, or a commitment to behave against his/her self-interest broadly construed. Accordingly, in the case of an incubator, as a university policy that is designed to develop social entrepreneurs, there are chances that the tenants may or may not choose to be social entrepreneurs as their achieved functions due to different choices they make.

Based on the above discussion, the application of the capability approach as an evaluative framework in assessing the role of a universitybased incubator in developing social entrepreneurs can be depicted in Figure 1. 


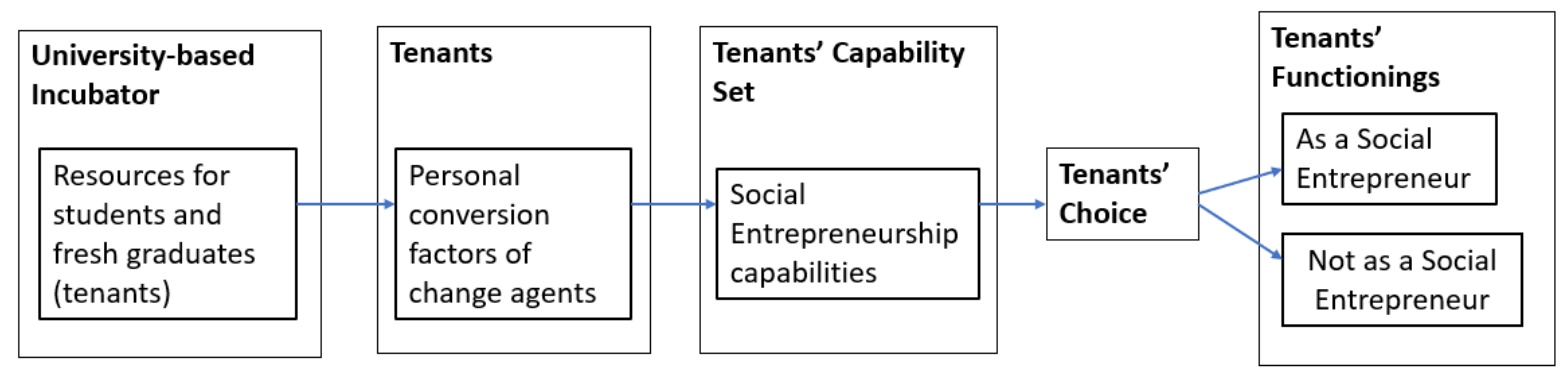

Figure 1. Theoretical Framework: Capability Approach Application in University-Based Incubator's Evaluation

\section{Contextualization: Creative Hub (C-Hub) of Gadjah Mada University (UGM)}

As one of the largest and oldest universities in Indonesia, UGM realized that universities are facing challenges due to the discrepancy between graduates' competencies and the current needs of the workforce, both in terms of quantity and quality. Consequently, many graduates are not able to compete to secure their desired jobs, or they have to wait a long time before getting a job. Consequently, UGM decided to make a breakthrough in its teaching and learning methods to keep up with the new challenges. It did so by establishing a Creative Hub (C-Hub) within the Faculty of Social and Political Science, in 2018.

The C-Hub is designed to bring social innovation to students and fresh graduates. As shown in Figure 2, it is the hub for resources and related stakeholders who care about developing the students' life skills. It focuses on social entrepreneurship's development for its tenants, who are selected through its talent pitching program. The talent pitching program invites students and fresh graduates who are interested in developing their ideas into a socially oriented business start-up. The selected talents will receive scholarships in the form of mentoring on various social entrepreneurship materials incorporated into the C-Hub's curriculum. The curriculum is designed to balance social and business perspectives, to maintain the sustainability of the social activities.
UGM has lucrative sources of tenants, who come from over 55,000 of its students, but more specifically from students who join the social entrepreneurship class, as well as students and fresh graduates who are already active as social entrepreneurs or small business owners. During the incubation program, tenants undergo a learning process which exposes them to knowledge about social science, management science and entrepreneurship, as well as the science of innovation, especially in the use of digital technology. One of the most important aspects of the curriculum is the social business model's design, which incorporates the community as the beneficiaries, unlike a profit-oriented business model that focuses on customers. Furthermore, the key activities of the social business model are the empowerment and capability building of the community. The business model should have a social mission to start with.

To ensure the sustainability of the business model, tenants receive weekly mentoring from experienced practitioners and academics; they share their progress with a public audience at sharing session events; enhance their knowledge through seminars with distinguished keynote speakers; present their achievements in demo day events; and receive counseling sessions to support and motivate them in achieving their social entrepreneurship endeavors. In sum, Figure 2 illustrates the role of $\mathrm{C}-\mathrm{Hub}$ as a learning ecosystem for students and fresh graduates of UGM. 


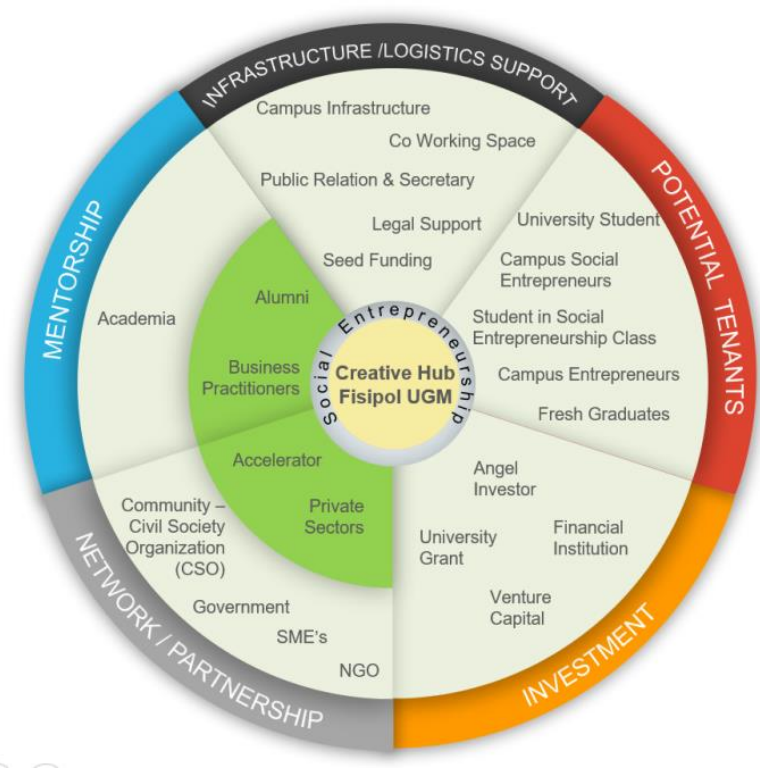

Source: C-Hub Documents

Figure 2. C-Hub as a Hub of University Resources for Social Entrepreneurship's Development

Table 1. C-Hub Talent Performance as of February 2020

\begin{tabular}{ccccccccc}
\hline Batches & Growing & Percent & Stagnant & Percent & Leaving & Percent & Total & Percent \\
\hline 1 & 8 & $53 \%$ & 1 & $7 \%$ & 6 & $40 \%$ & 15 & $100 \%$ \\
2 & 2 & $20 \%$ & 3 & $30 \%$ & 5 & $50 \%$ & 10 & $100 \%$ \\
3 & 9 & $64 \%$ & 1 & $7 \%$ & 4 & $29 \%$ & 14 & $100 \%$ \\
Total & 19 & $49 \%$ & 5 & $13 \%$ & 15 & $38 \%$ & 39 & $100 \%$ \\
\hline
\end{tabular}

Source: C-Hub Documents

Up to February 2020, C-Hub had conducted three series of talent pitching. Based on C-Hub's evaluation, the performance of the tenants can be summarized in Table 1. As shown in Table 1, the current evaluation of C-Hub shows that 19 tenants (49\%) have growing businesses, five tenants $(13 \%)$ are stagnant and are in the process of reconsidering their business models, and 15 tenants $(38 \%)$ have decided to do another form of business or have taken jobs that do not involve them in becoming social entrepreneurs. The fact that almost $40 \%$ of the tenants decided not to continue their functions as social entrepreneurs after their incubation process has triggered CHub's management to evaluate the role of C-Hub in developing social entrepreneurship, and to explore why tenants decide to be, or not to be, social entrepreneurs after being incubated.

\section{METHOD, DATA, AND ANALYSIS}

This study applied a case study approach (Stake, 2000; Yin, 2003, 2009) to investigate the role of a university-based incubator in developing social entrepreneurship, and to explore why tenants decide to be, or not to be, social entrepreneurs after being incubated. Case studies have been found to be suitable to illuminate how the process evolves over time under a certain topic of study (Yin, 2009). The data collection was conducted from February to May 2020. C-Hub was chosen for the theoretical or purposive sampling because it met the criteria of an "exemplary case study" (Eisenhardt \& Graebner, 2007, p.27) having been previously chosen as a good example of a social 
entrepreneurship incubator by the British Council 2019. Accordingly, C-Hub can represent a "unique" and "revelatory" case (Yin, 2009, p. 47) in answering the research questions.

This study used three sources of evidence: documents, interviews, and focus group discussions (FGDs). First, we analyzed the contents of the tenants' performance evaluations (content analysis) to categorize the progress of the tenants, which is summarized in Table 1 above. Subsequently, we selected the participants of two focus group discussions (FGDs) on February 17, 2020. The purpose of the FGDs was to obtain an understanding about the tenants' inputs on the role of C-Hub in improving their performance, and the reasons why some tenants choose not to continue their functions as social entrepreneurs. Rabiee (2004) suggests that up to 10 participants in one FGD is a good size. Accordingly, we invited seven tenants to each FGD session or a total of 14 tenants for the two sessions held on February 17, 2020. For the FGDs, we prepared a semi-structured question aimed at obtaining the participants' insights about the effectiveness of C-Hub's services and how those indicators influenced the tenants' performance. We also had questions related to why some tenants decided to be, or not to be, social entrepreneurs after the incubation process. The profiles of the FGDs participants are listed in Table 2.

Table 2. Profiles of Focus Group Discussion Participants

\begin{tabular}{|c|c|c|c|}
\hline No & $\begin{array}{l}\text { Tenants/Batch/ } \\
\text { Status }\end{array}$ & Social Entrepreneurship Area & Progress \\
\hline 1 & $\begin{array}{l}\text { Ailesh Power/Batch } \\
\text { 1/ Students }\end{array}$ & $\begin{array}{l}\text { Renewable energy with raw materials } \\
\text { from domestic and industrial waste }\end{array}$ & $\begin{array}{l}\text { Very successful; already collaborated } \\
\text { with private sector and university; } \\
\text { already received investment }\end{array}$ \\
\hline 2 & $\begin{array}{l}\text { Bantu/Batch 1/ } \\
\text { Fresh Graduates }\end{array}$ & $\begin{array}{l}\text { Mobile application for on the road } \\
\text { emergency assistance provided by } \\
\text { civilians }\end{array}$ & $\begin{array}{l}\text { Very successful; already collaborated } \\
\text { with provincial government and } \\
\text { university; already received investment }\end{array}$ \\
\hline 3 & $\begin{array}{l}\text { Dmilk/Batch 1/ } \\
\text { Students }\end{array}$ & $\begin{array}{l}\text { Pasteurized milk, collaborating with } \\
\text { local milk farmers. }\end{array}$ & $\begin{array}{l}\text { Very successful; working together with } \\
\text { dairy farmers in Sleman region. }\end{array}$ \\
\hline 4 & $\begin{array}{l}\text { Kartitedjo/ Batch 1/ } \\
\text { Fresh Graduates }\end{array}$ & $\begin{array}{l}\text { Cultural preservation through audio } \\
\text { visual content. }\end{array}$ & $\begin{array}{l}\text { Very successful; received many orders } \\
\text { from the government and private sector } \\
\text { to preserve local culture. }\end{array}$ \\
\hline 5 & $\begin{array}{l}\text { Lomba Mahasiswa/ } \\
\text { Batch 2/ Students }\end{array}$ & $\begin{array}{l}\text { Digital platform to connect the } \\
\text { creators of student competitions with } \\
\text { students as contestants }\end{array}$ & $\begin{array}{l}\text { Very successful. Growing business } \\
\text { reaching international users. }\end{array}$ \\
\hline 6 & $\begin{array}{l}\text { Neo Wedding } \\
\text { Singer/ Batch 2/ } \\
\text { Fresh Graduates }\end{array}$ & $\begin{array}{l}\text { Event organizer that bridges talent } \\
\text { with users; providing high quality } \\
\text { entertainment with professional talent } \\
\text { from creative industry. }\end{array}$ & $\begin{array}{l}\text { Very successful. Growing customers and } \\
\text { well-known in the industry }\end{array}$ \\
\hline 7 & $\begin{array}{l}\text { EBete / Batch 3/ } \\
\text { Post graduate } \\
\text { students }\end{array}$ & $\begin{array}{l}\text { Renewable energy using waste to } \\
\text { produce alternative energy like biogas, } \\
\text { turbine, electricity }\end{array}$ & $\begin{array}{l}\text { Very successful. Collaborating with } \\
\text { Ailesh Power (tenant no. 1) to handle one } \\
\text { of Ailesh's projects }\end{array}$ \\
\hline 8 & $\begin{array}{l}\text { Mimi Basi/Batch 3/ } \\
\text { Students }\end{array}$ & $\begin{array}{l}\text { High quality, healthy fermented drinks } \\
\text { for lower income people. }\end{array}$ & $\begin{array}{l}\text { Very successful; have received repeated } \\
\text { orders and growing market }\end{array}$ \\
\hline 9 & $\begin{array}{l}\text { Rumah Harmonis/ } \\
\text { Batch 3/ Students }\end{array}$ & $\begin{array}{l}\text { Digital platform to provide } \\
\text { consultation and support for mental } \\
\text { health for all levels of income. }\end{array}$ & $\begin{array}{l}\text { Developing; it is in the process of } \\
\text { developing platform. }\end{array}$ \\
\hline 10 & $\begin{array}{l}\text { Sida Tani/ Batch 3/ } \\
\text { Fresh Graduates }\end{array}$ & $\begin{array}{l}\text { A platform to support village and } \\
\text { agricultural ecosystem in building } \\
\text { village agricultural industry and eco- } \\
\text { tourism. }\end{array}$ & $\begin{array}{l}\text { Very successful; gained a lot of } \\
\text { partnerships after joining C-Hub; has } \\
\text { developed workable business model. }\end{array}$ \\
\hline 11 & $\begin{array}{l}\text { Kayuku/ Batch 2/ } \\
\text { Students }\end{array}$ & $\begin{array}{l}\text { Converting teak wood waste into high } \\
\text { value handicrafts }\end{array}$ & $\begin{array}{l}\text { Stagnant. In the process of fine-tuning its } \\
\text { business model }\end{array}$ \\
\hline
\end{tabular}




\begin{tabular}{|c|c|c|c|}
\hline No & $\begin{array}{l}\text { Tenants/Batch/ } \\
\text { Status }\end{array}$ & Social Entrepreneurship Area & Progress \\
\hline 12 & $\begin{array}{l}\text { Librario/ Batch 2/ } \\
\text { Students }\end{array}$ & $\begin{array}{l}\text { Online platform to lend and borrow } \\
\text { books to enhance literacy }\end{array}$ & $\begin{array}{l}\text { Stagnant. A growing Librario } \\
\text { community; in the process of finding the } \\
\text { right business model. }\end{array}$ \\
\hline 13 & $\begin{array}{l}\text { Bawana/Batch 2/ } \\
\text { Students }\end{array}$ & $\begin{array}{l}\text { A fashion brand to bridge creative } \\
\text { fashion designers with the market }\end{array}$ & $\begin{array}{l}\text { Stagnant. In the process of fine-tuning its } \\
\text { business model }\end{array}$ \\
\hline 14 & $\begin{array}{l}\text { Core-Lab/Batch 3/ } \\
\text { Fresh Graduates }\end{array}$ & $\begin{array}{l}\text { Crowdfunding digital platform for } \\
\text { research and innovation }\end{array}$ & $\begin{array}{l}\text { Stagnant. In the process of fine-tuning its } \\
\text { business model }\end{array}$ \\
\hline
\end{tabular}

Source: C-Hub Documents and Authors' Analysis

For the data analysis we conducted content analysis (Morgan, 1997, 2014) from the FGDs manually. We applied coding to categorize, eliminate, combine and subdivide the data and to record and see connections among the themes that we want to observe (Charmaz, 2014). For the conclusions, we performed pattern matching techniques (Yin, 2009) to compare the empirical findings with the research framework (Eisenhardt, 1989; Eisenhardt \& Graebner, 2007; Yin, 2009).

\section{RESULT AND DISCUSSION}

This section is divided into three subsections. Subsection 3.1 shows the demographic profile of the tenants. Subsection 3.2 discusses the result and analysis for the first research question on "the role of a university-based incubator in developing social entrepreneurship." Subsequently, subsection 3.3 presents the second research question on "why tenants choose other professions rather than being social entrepreneurs, after being incubated."

\section{Demographic Profile of Tenants}

Based on documents and archival records from CHub, the tabulation of the tenants' demographic profiles is presented in Table 3. Since its establishment in 2018, C-Hub has conducted three series of talent pitching and selected 39 tenants. As shown in Table 1, the majority of the tenants are male; under 27 years old; undergraduate students; and joined C-Hub at the stage of business idea.

\section{The roles of a university-based incubator in developing social entrepreneurship}

This subsection answers the research question on "the role of a university-based incubator in developing social entrepreneurship." As discussed below, the study finds that the university-based incubator has developed social entrepreneurship by providing its tenants with university resources, enhancing their social entrepreneurship capabilities, improving their entrepreneurship performance, and developing their personal conversion factors as agents for change.

\subsection{A university-based incubator as a hub of university resources for tenants}

All 14 FGD participants appreciate the fact that Gadjah Mada University established and implemented the policy to support social entrepreneurship's development through C-Hub. The tenants recognize the importance of C-Hub's resources in five areas: infrastructure, administrative, capacity building, access to finance, and social networking, as summarized in points R-1 to R-12 in Table 4. 
Table 3. Demographic Profile of C-Hub's Tenants

\begin{tabular}{lcc}
\hline \multicolumn{1}{c}{ Demographic Information } & Number of tenants & Percentage \\
\hline Founder's Gender & & \\
- Female & 8 & $20.5 \%$ \\
- Male & 31 & $79.5 \%$ \\
Founder's Age & & \\
- 20 - 23 years old & 17 & $43.6 \%$ \\
- 24 - 27 years old & 14 & $35.9 \%$ \\
- above 27 years old & 8 & $20.5 \%$ \\
Level of Education & & \\
- Bachelor students & 25 & $64.1 \%$ \\
- Master students & 3 & $7.7 \%$ \\
- Fresh Graduates with bachelor's degree & 11 & $28.2 \%$ \\
Stage when joining Incubator & & \\
- Business idea & 25 & $64.1 \%$ \\
- Start-up & 14 & $35.9 \%$ \\
Number of team members (including founder) & & \\
- 1 - 2 people & 18 & $46.2 \%$ \\
- 3 - 4 people & 20 & $51.3 \%$ \\
- above 4 people & 1 & $2.6 \%$ \\
\hline Source: C-Hub Documents and Authors' Analysis & & \\
\hline
\end{tabular}

Table 4. C-Hub Resources for Tenants (Students and Fresh Graduates)

\begin{tabular}{|c|c|c|c|}
\hline Codes & Resources & $\begin{array}{l}\text { Mentioned by } \\
\text { (Tenants) }\end{array}$ & Examples of Evidence \\
\hline $\mathrm{R}-1$ & Office and working areas & $\begin{array}{l}\text { Mimi Basi, Ailesh } \\
\text { Power, D’Milk, Lomba } \\
\text { Mahasiswa }\end{array}$ & "We use the office space a lot" (D’Milk) \\
\hline $\mathrm{R}-2$ & $\begin{array}{l}\text { Business address provided } \\
\text { for tenants }\end{array}$ & $\begin{array}{l}\text { Ailesh Power, Ebete, } \\
\text { D’Milk }\end{array}$ & $\begin{array}{l}\text { "Business address is very important as we } \\
\text { still don't have our own office" (Ebete) }\end{array}$ \\
\hline $\mathrm{R}-3$ & $\begin{array}{l}\text { Shared services: meeting } \\
\text { areas, photocopier, printer }\end{array}$ & $\begin{array}{l}\text { Mimi Basi, Ailesh } \\
\text { Power, D'Milk }\end{array}$ & $\begin{array}{l}\text { "Shared services are very useful as we get to } \\
\text { know each other by using them together" } \\
\text { (Ailesh Power) }\end{array}$ \\
\hline $\mathrm{R}-4$ & $\begin{array}{l}\text { Support for the sales and } \\
\text { marketing of products and } \\
\text { services }\end{array}$ & D’Milk & $\begin{array}{l}\text { "On many occasions, C-Hub orders their } \\
\text { refreshments from us" (D'Milk) }\end{array}$ \\
\hline $\mathrm{R}-5$ & $\begin{array}{l}\text { Assistance with } \\
\text { administrative and secretarial } \\
\text { services }\end{array}$ & Kartitedjo, Sidatani & $\begin{array}{l}\text { "We use the administrative and secretarial } \\
\text { services to help us" (Kartitedjo) }\end{array}$ \\
\hline $\mathrm{R}-6$ & $\begin{array}{l}\text { Business training, seminars } \\
\text { and workshops }\end{array}$ & Bawana, Sidatani & $\begin{array}{l}\text { "I attend the workshops and Demoday for } \\
\text { my knowledge building" (Bawana) }\end{array}$ \\
\hline $\mathrm{R}-7$ & $\begin{array}{l}\text { Business counseling and } \\
\text { mentoring }\end{array}$ & $\begin{array}{l}\text { Indischool, Core Lab, } \\
\text { Bawana, Kayuku }\end{array}$ & $\begin{array}{l}\text { "C-Hub's coaching and mentoring are crucial } \\
\text { for me to find the workable business models" } \\
\text { (Indischool) }\end{array}$ \\
\hline $\mathrm{R}-8$ & $\begin{array}{l}\text { Support for business } \\
\text { planning and development }\end{array}$ & Bawana, Ailesh Power & $\begin{array}{l}\text { "C-Hub assists me to understand how to } \\
\text { achieve business and social purposes } \\
\text { simultaneously" (Bawana) }\end{array}$ \\
\hline
\end{tabular}




\begin{tabular}{|c|c|c|c|}
\hline Codes & Resources & $\begin{array}{l}\text { Mentioned by } \\
\text { (Tenants) }\end{array}$ & Examples of Evidence \\
\hline R-9 & $\begin{array}{l}\text { Peer networking (sharing } \\
\text { sessions for experience, } \\
\text { partnerships building, } \\
\text { motivation) }\end{array}$ & $\begin{array}{l}\text { Bawana, Mimi Basi, } \\
\text { Sidatani, Ebete, } \\
\text { IndiSchool) }\end{array}$ & $\begin{array}{l}\text { "We generate ideas and build collaborations } \\
\text { with other tenants" (Bawana) }\end{array}$ \\
\hline $\mathrm{R}-10$ & $\begin{array}{l}\text { Access to finance (grants, } \\
\text { and loans) }\end{array}$ & $\begin{array}{l}\text { Rumah Harmonis, } \\
\text { Ailesh Power }\end{array}$ & $\begin{array}{l}\text { "We generate funding, and get grants from } \\
\text { UGM" (Rumah Harmonis, Ailesh Power) }\end{array}$ \\
\hline $\mathrm{R}-11$ & $\begin{array}{l}\text { Access to potential } \\
\text { customers }\end{array}$ & New Wedding Singer & $\begin{array}{l}\text { "We find ways to open new branches and } \\
\text { improve customer's satisfaction" (New } \\
\text { Wedding Singer) }\end{array}$ \\
\hline $\mathrm{R}-12$ & $\begin{array}{l}\text { Access to external resources } \\
\text { and information (experts, } \\
\text { government, universities, } \\
\text { partners, etc.) }\end{array}$ & $\begin{array}{l}\text { Ailesh Power, Core } \\
\text { Lab, Ebete }\end{array}$ & $\begin{array}{l}\text { "We have investors and networks from } \\
\text { governments, from C-Hub" (Core Lab). }\end{array}$ \\
\hline
\end{tabular}
2.2. Social Entrepreneurship Capabilities developed by $\mathrm{C}-\mathrm{Hub}$

In terms of their capabilities, the FGD participants stated that they gained seven social entrepreneurship capabilities after joining C-Hub, as summarized in Table 5 points $\mathrm{C}-1$ to $\mathrm{C} 7$.

Table 5. Social Entrepreneurship Capabilities

\begin{tabular}{|c|c|c|c|}
\hline Codes & $\begin{array}{l}\text { Social Entrepreneurship } \\
\text { Capabilities }\end{array}$ & $\begin{array}{l}\text { Mentioned by } \\
\text { (Tenants) }\end{array}$ & Examples of Evidence \\
\hline $\mathrm{C}-1$ & $\begin{array}{l}\text { Convinced about sustainability } \\
\text { of tenants' social enterprise } \\
\text { after graduating from C-Hub }\end{array}$ & $\begin{array}{l}\text { New Wedding Singer, } \\
\text { Sidatani, Kayuku, Mimi } \\
\text { Basi, Ailesh Power, } \\
\text { Kartitedjo }\end{array}$ & $\begin{array}{l}\text { "After joining C-Hub, we find the business } \\
\text { model that will benefit the business and the } \\
\text { society" (Mimi Basi) }\end{array}$ \\
\hline $\mathrm{C}-2$ & $\begin{array}{l}\text { Foreseen potential profit } \\
\text { growth of tenants' producs/ } \\
\text { services }\end{array}$ & New Wedding Singer & $\begin{array}{l}\text { "We expand our market share and } \\
\text { penetration" (New Wedding Singer) }\end{array}$ \\
\hline C-3 & $\begin{array}{l}\text { Improvements in tenants' } \\
\text { business knowledge and skills }\end{array}$ & Mimi Basi & $\begin{array}{l}\text { "We improve our communication skills for } \\
\text { our pitches, and enhance our business } \\
\text { model" (Mimi Basi) }\end{array}$ \\
\hline C-4 & $\begin{array}{l}\text { Improvements in tenants' } \\
\text { professionalism }\end{array}$ & Bawana & $\begin{array}{l}\text { "When our project gets stuck, the } \\
\text { knowledge from C-Hub can be considered } \\
\text { as a life skill that is applicable in other } \\
\text { areas" (Bawana) }\end{array}$ \\
\hline C-5 & $\begin{array}{l}\text { Productive networking with } \\
\text { other tenants of C-Hub }\end{array}$ & $\begin{array}{l}\text { Rumah Harmonis, Mimi } \\
\text { Basi, D’Milk, Core-Lab, } \\
\text { Ailesh Power, Ebete' } \\
\text { Kartitedjo }\end{array}$ & $\begin{array}{l}\text { "From our regular meetings with C-Hub and } \\
\text { other tenants, we build collaborations to } \\
\text { enhance our business" (Core-Lab) }\end{array}$ \\
\hline C-6 & $\begin{array}{l}\text { Improvements in the reputation } \\
\text { and credibility of the tenants }\end{array}$ & Kartitedjo & $\begin{array}{l}\text { "Gadjah Mada University has a very good } \\
\text { reputation; that helps us a lot because } \\
\text { people see us as part of the university" } \\
\text { (Kartitedjo) }\end{array}$ \\
\hline $\mathrm{C}-7$ & $\begin{array}{l}\text { Networking with relevant } \\
\text { stakeholders (suppliers, } \\
\text { customers, professional } \\
\text { support, etc.) }\end{array}$ & $\begin{array}{l}\text { Ailesh Power; Core-Lab, } \\
\text { Ebete }\end{array}$ & $\begin{array}{l}\text { "Now we are able to build networks with } \\
\text { relevant stakeholders; we get support for the } \\
\text { project, from the Ministries, State-Owned } \\
\text { Electricity Company and Private } \\
\text { Companies" (Ailesh Power, Core-Lab, } \\
\text { Ebete) }\end{array}$ \\
\hline
\end{tabular}




\subsection{Social Entrepreneurship Performance/}

Functionings developed by $\mathrm{C}-\mathrm{Hub}$

The FGD participants acknowledge improvements in seven areas of their social entrepreneurship's performance as the outcome of joining C-Hub, as summarized in Table 6 points F1 to F7.

\subsection{Tenants' personal conversion factors as agents for change}

The results of the FGDs show that all the tenants have personal conversion factors for making social change, in terms of their educational backgrounds, interests, ideas, passions, and social missions when joining C-Hub. They recognize that C-Hub has enhanced their personal conversion factors, allowing them to convert resources into social entrepreneurship capabilities and functions. For example, Indischool admits that,
When I came here, I had a full social mission. From C-Hub I learnt that we need to learn about the sustainability of the business. Before we thought that having a business mindset is a 'taboo' thing when we want to tackle social issues. Now our mindset has changed. We see that business and societal causes can work hand in hand. (FGD with Indischool, February 17, 2020).

Furthermore, C-Hub has also enabled its tenants to transfer their ideas into actions that benefit society, as expressed by Core Lab in the area of sustainable energy,

I have a nuclear engineering background, but I am very interested in social causes. I have travelled to remote areas of Indonesia, so I want to provide energy for communities in remote areas who do not have access to technology and innovation. I joined C-Hub so I can transfer my ideas into products and services that can be shared with others in sustainable ways. (FGD with Core Lab, February 17, 2020).

Table 6. Social Entrepreneurship Performance

\begin{tabular}{|c|c|c|c|}
\hline Codes & $\begin{array}{c}\text { Social Entrepreneurship } \\
\text { Performance } \\
\end{array}$ & $\begin{array}{c}\text { Mentioned by } \\
\text { (Tenants) }\end{array}$ & Examples of Evidence \\
\hline F-1 & $\begin{array}{l}\text { Improvement to the impacts on the } \\
\text { community that we serve }\end{array}$ & $\begin{array}{l}\text { Kayuku, Sidatani, } \\
\text { LombaMahasiswa }\end{array}$ & $\begin{array}{l}\text { "We improve our production processes; } \\
\text { and the community becomes our } \\
\text { suppliers" (Kayuku) }\end{array}$ \\
\hline $\mathrm{F}-2$ & $\begin{array}{l}\text { Improvement in the productivity of } \\
\text { tenants' social enterprise team }\end{array}$ & Kayuku & $\begin{array}{l}\text { "We develop our business vision here and } \\
\text { we develop our human resources here, } \\
\text { too" (Kayuku) }\end{array}$ \\
\hline F-3 & $\begin{array}{l}\text { Faster promotion and introduction } \\
\text { of tenants' social businesses to } \\
\text { communities and partners }\end{array}$ & D’Milk & $\begin{array}{l}\text { "We developed our market by introducing } \\
\text { milk subscription" (D’Milk) }\end{array}$ \\
\hline $\mathrm{F}-4$ & $\begin{array}{l}\text { Tenants' effectiveness in } \\
\text { delivering their social businesses' } \\
\text { missions to the community they } \\
\text { serve }\end{array}$ & Kayuku, Sidatani & $\begin{array}{l}\text { "We always think about the social impacts } \\
\text { when helping the community that we } \\
\text { serve" (Sidatani) }\end{array}$ \\
\hline F-5 & $\begin{array}{l}\text { Increase in the number of tenants' } \\
\text { team members }\end{array}$ & $\begin{array}{l}\text { Kartitedjo, } \\
\text { RumahHarmonis }\end{array}$ & $\begin{array}{l}\text { "Our team members are growing so it is } \\
\text { easier for us to run our business" } \\
\text { (Kartitedjo) }\end{array}$ \\
\hline F-6 & Increase in investment and funding & $\begin{array}{l}\text { Ailesh Power, Core } \\
\text { Lab, Ebete }\end{array}$ & $\begin{array}{l}\text { "We receive investments from other } \\
\text { parties" (Ailesh Power) }\end{array}$ \\
\hline F-7 & $\begin{array}{l}\text { The income of tenants' team } \\
\text { members has increased }\end{array}$ & $\begin{array}{l}\text { New Wedding Singer, } \\
\text { Kartitedjo }\end{array}$ & $\begin{array}{l}\text { "We receive many orders, hence } \\
\text { increasing the income of people within } \\
\text { our social enterprise" (Kartitedjo) }\end{array}$ \\
\hline
\end{tabular}


Similarly, C-Hub helped Mimi Basi to findg its business model for affordable fermented drinks,

I see that fermented drinks are very good for people's digestive systems, but the price is so expensive, especially in cafes. Therefore, I came to C-Hub to learn how I can make the drinks affordable and it became a successful business. (FGD with Mimi Basi, February 17, 2020)

Overall, as agents for change, all the tenants have a social mission to contribute to the SDGs as tabulated in Table 7. Based on our document analysis of C-Hub, the 39 tenants incubated by CHub operate their social enterprises in the areas of sustainable energy, emergency response, environmental protection, transportation, nutritious food and drinks, the preservation of local culture, education and mental health, employment, literacy, agriculture, and mental health. Because of the interrelations between the areas of the SDGs, one tenant can cover more than one of the SDGs' development areas. Hence, from the multiple answers to the SDGs' areas, C-Hub tenants have covered 16 of the 17 sustainable development goals, as presented in Table 7 .

\section{Tenants' choice to perform as social entrepreneurs or other functions}

This section answers the second research question, which is "why tenants choose other professions rather than being social entrepreneurs after being incubated." As shown in Table 1, the current evaluation of C-Hub shows that 19 tenants (49\%) have growing businesses, five tenants (13\%) are stagnant and are in the process of reconsidering their business models, and 15 tenants $(38 \%)$ have decided to do a different kind of business or take other jobs rather than becoming social entrepreneurs. Tenants make choices to decide whether they want to continue their efforts to become social entrepreneurs, or do other things as their functions. Interviews with the management of C-Hub reveal that several tenants decided to accept jobs in large companies, usually in the companies' corporate social responsibility or community engagement departments. It shows that C-Hub has developed transferable capabilities in the area of social change, as mentioned by an FGD participant,

Table 7. Tenants' Area Related to Sustainable Development Goals (SDGs)

\begin{tabular}{lcc}
\hline \multicolumn{1}{c}{ SDGs Covered } & $\begin{array}{c}\text { Multiple } \\
\text { answers }\end{array}$ & $\%$ Tenants \\
\hline 1. No Poverty & 13 & $33 \%$ \\
2. Zero Hunger & 2 & $5 \%$ \\
3. Good Health and Well-being & 9 & $23 \%$ \\
4. Quality Education & 12 & $31 \%$ \\
5. Gender Equality & 3 & $8 \%$ \\
6. Clean Water and Sanitation & 3 & $8 \%$ \\
7. Affordable and Clean Energy & 4 & $10 \%$ \\
8. Decent Work and Economic Growth & 5 & $13 \%$ \\
9. Industry, Innovation, and Infrastructure & 9 & $23 \%$ \\
10. Reducing Inequality & 3 & $8 \%$ \\
11. Sustainable Cities and Communities & 10 & $26 \%$ \\
12. Responsible Consumption and Production & 2 & $5 \%$ \\
13. Climate Action & 5 & $13 \%$ \\
14. Life Below Water & 0 & $0 \%$ \\
15. Life on Land & 1 & $3 \%$ \\
\hline
\end{tabular}




\begin{tabular}{lcc}
\hline \multicolumn{1}{c}{ SDGs Covered } & $\begin{array}{c}\text { Multiple } \\
\text { answers }\end{array}$ & $\%$ Tenants \\
\hline 16. Peace, Justice, and Strong Institutions & 12 & $31 \%$ \\
17. Partnerships for the Goals & 18 & $46 \%$ \\
\hline
\end{tabular}

The spirit of social entrepreneurship and our skills' development are very useful. Even when our project gets stuck, the knowledge from $\mathrm{C}$-Hub can be considered as a life skill that is applicable in other areas. (FGD with Bawana, 17 February 2020).

Overall, as suggested by the capability approach, choice is the freedom for people to determine what really matters to them to pursue in their lives (Sen, 1992; 1999). The results show that the social entrepreneurship capabilities developed by C-Hub become transferable skills that give more freedom for the tenants to make choices about their functions.

\section{DISCUSSION}

This study supports the assertion that the development policy of an institution should be aimed at expanding the freedom of people to get the resources they need to achieve their functions (Alkire, 2005). In this case, Gadjah Mada University has developed and implemented its policy for developing the social entrepreneurship of its students and fresh graduates through the $\mathrm{C}$ Hub. The results illuminate the role of a university-based incubator as a hub for the resources that enhance the tenants' personal conversion factors. As suggested by Robeyns, (2017), different people can achieve different levels of well-being or functioning depending on their personal conversion factors, and the influence of their social and environmental conditions (Robeyns, 2017). Accordingly, by having enhanced personal conversion factors, because of their improved capabilities, the tenants can convert resources into social entrepreneurship functions. Hence, they become effective agents for change when making social changes.
Furthermore, our findings show that the tenants receive many benefits and support from the incubation program. In general, the tenants admit that the $\mathrm{C}-\mathrm{Hub}$ has functioned as an enabler for their social enterprises' improvements. C-Hub has enhanced their personal conversion factors by improving their business competence though mentoring, training, coaching, and consultation, as well as providing funding and networking support. What C-Hub has done is in line with experts' opinions that it was established to provide support for startups or tenants in the form of infrastructure, services, and resources (Bruneel et al., 2012; Mas-Verdú, et al., 2015).

Overall, as presented in Figure 2 above, CHub intends to be a hub for the resources that provide a learning ecosystem for the tenants. It encompasses the development of social entrepreneurship's core curriculum by C-hub; the provision of office infrastructure and logistical support; mentoring opportunities; networking and partnership opportunities; and investment opportunities. This study finds that C-Hub's tenants appreciate the opportunities they were given to be incubated in such a learning environment. Overall, C-Hub has met the performance requirements of an incubator, with both its infrastructure and support system, which were previously studied by other researchers (Lasrado et al., 2016; Albort-Morant \& Oghazi, 2016).

Interestingly, despite the availability of the infrastructure and support to all the tenants, there are variations in the tenants' social entrepreneurship performances or functions, as previously mentioned. Of the 39 tenants so far, there are 19 (49\%) whose businesses are growing, five tenants' $(13 \%)$ businesses are stagnant or in the process of being reconsidered, and 15 tenants 
(38\%) have decided to do another type of business or take other jobs, rather than become social entrepreneurs. A remarkable finding from the incubated tenants is that they have the social entrepreneurship capabilities to produce social innovations. They have valuable propositions/business ideas which are needed by customers. Their social mission can be carried out with a business approach that involves the community and the beneficiaries. As stated by Sinthupundaja et al. (2020), social innovation could be improved with cross-sector collaboration capabilities, and entrepreneurial practices could be strengthened by greater stakeholder management capabilities. The capability approach has been able to illuminate that an "act of choice" is necessary to move from capabilities to functions (Robeyns, 2017).

Hence, while having enhanced capability sets, some tenants may choose to work in other professions or matters as their function. This is in line with the expected utility theory which assumes individuals are rational (Edwards, 1954; Schoemaker, 1982), including when they want to choose a career. Their rationality will trigger them to choose a career path that maximizes their utility by calculating the expected value of each career option, and the success probability of each option. Individuals who prioritize their personal well-being may choose to work for large companies or start their own commercial enterprises, while those who are driven by their commitment to help others and contribute to the community at large may choose to become social entrepreneurs.

In this case, based on the evaluation record, the tenants with good social entrepreneurial performances have kept in touch with C-Hub, and serve as mentors or partners to other tenants. For example, three tenants that share visions in sustainable energy (Ailesh Power, Core Lab, and Ebete) are collaborating to work on projects with the government and other investors. Hence, there is a feedback loop to C-Hub from the tenants who choose to become social entrepreneurs.

Nevertheless, there are also several tenants that have chosen to work in large companies, taking positions in their community engagement or corporate social responsibility departments. This fact shows that the nature of work chosen by the tenants is still related to social change.

The above empirical findings have enhanced our knowledge on the application of the capability approach for evaluating the role of universitybased incubators. A visual arrangement of the linkages among the concepts of the capability approach, in the context of a university-based incubator, is depicted in Figure 3. The model was developed based on the empirical evidence found during the evaluation of the role of the Creative Hub (C-Hub) of Gadjah Mada University (UGM) in developing the social entrepreneurship capabilities of its students and fresh graduates of UGM.

Figure 3. A Model of University-Based Incubator's Role in Developing Social Entrepreneurs. 


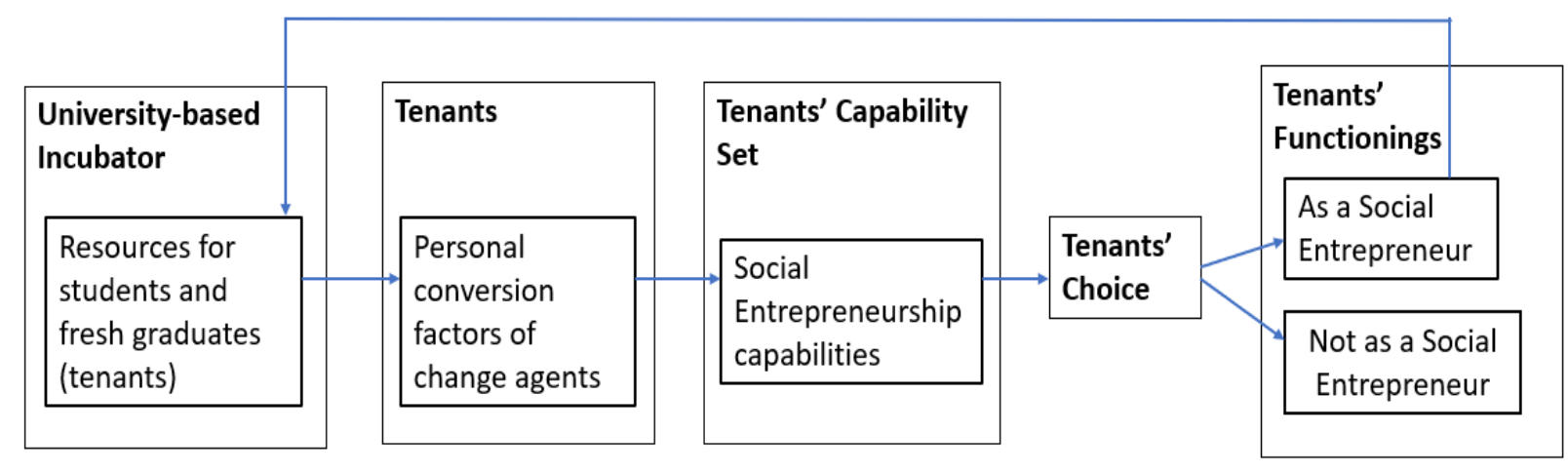

\section{CONCLUSION}

To conclude, this study has achieved its objective by explaining the role of university-based incubators in the social entrepreneurship development of students and fresh graduates, by using the capability approach as an evaluative framework. The research shows a virtuous cycle of the university's policy to build the capabilities and functions of students and fresh graduates in becoming social entrepreneurs. This study reveals that the university-based incubator serves as a hub for the resources that enhance the tenants' personal conversion factors; thereby they can be more effective agents for change (social entrepreneurs). With continuous support from the incubators, the tenants will have the necessary capability sets to perform as social entrepreneurs, as their valuable beings and doings (functions). For those who choose to be social entrepreneurs, they can contribute to the incubator by sharing their experience, skills, and knowledge by being mentors or coaches. Nevertheless, the capability approach recognizes that the real capabilities of the tenants come from their freedom to make a choice as to whether they want to be, or not to be, social entrepreneurs.

This study contributes to the literature on the capability approach, social entrepreneurship and university-based business incubation by illuminating the linkages among the different concepts of the capability approach in university-based social entrepreneurship's development. The model generated from this research can be replicated by other universities which intend to establish university incubators to develop social entrepreneurship. However, this research has a limitation as it is a case study of a single incubator. Further quantitative research needs to be conducted to validate the qualitative findings about the indicators generated from the FGDs, with wider samples for a broader generalizability.

\section{ACKNOWLEDGEMENT}

The authors wish to thank the reviewers of the 2020 HDCA conference paper for their helpful comments and feedback.

\section{REFERENCE}

Albort-Morant, G., \& Pejvak, O. (2016). How useful are incubators for new entrepreneurs?. Journal of Business Research, 69(6), 212529.

Alkire, S. (2002). The capability approach and human development.Oxford Poverty \& Human Development Initiative, 9, 1-60.

Alkire, S. (2005). Why the capability approach?. Journal of Human Development, 6(1), 11535 .

Audretsch, D.B. (2017). Entrepreneurship and universities. Int. J. Entrepreneurship and Small Business, 31(1), 4-11.

Ayatse, F.A., Nguwasen, K., \& Akuraun S. I. (2017). Business incubation process and firm 
performance: An empirical review. Journal of Global Entrepreneurship Research, 7(1), $1-17$.

Bacq, S., \& Janssen, F. (2011). The multiple faces of social entrepreneurship: A review of definitional issues based on geographical and thematic criteria. Entrepreneurship and Regional Development, 23(5), 373-403.

BAPPENAS. (2016). Penguatan UKM untuk pertumbuhan ekonomi yang berkualitas. Warta KUKM, 5(1), 4-8.

Bennett, D., Yábar, D.P.B., \& Saura, J. R. (2017). University incubators maybe socially valuable, but how effective are they? A case study on business incubators at universities.In J.A. Peris-Ortiz et al. (Eds.), Entrepreneurial Universities Exploring the Academic and Innovative Dimensions of Entrepreneurship in Higher Education 
(pp.165-177), Springer International Publishing.

Bhardwaj, R., \& Christie, R. (2018).Start-up assistance organizations in Indonesia: Performance, challenges and solutions special focus on gender inclusion. Retrieved from https://www.spf.org/en/global-data/ SAO-Performance-Challenges-

Solutions.pdf.

Bornstein, D., \& Susan D. (2010).Social entrepreneurship: What everyone needs to know. Oxford: Oxford University Press.

Briggs, R. A. (2019). Normative theories of rational choice: Expected utility. In E.N. Zalta (Ed.) The Stanford Encyclopedia of Philosophy (Fall 2019 Edition). Retrieved from

https://plato.stanford.edu/archives/fall2019/ entries/rationality-normative-utility/.

British Council. (2018).Building an inclusive and creative economy: The state of social enterprise in Indonesia. Retrieved from https://www.unescap.org/news/britishcouncil-and-united-nations-escap-launchlandmark-indonesia-social-enterpriselandscape.

Bruneel, J., Tiago, R., Bart, C., \& Groen, A. (2012). The evolution of business incubators: Comparing demand and supply of business incubation services across different incubator generations.Technovation, 32(2), 110-21.

Charmaz, K. (2014). Constructing grounded theory: Constructing grounded theory $\left(2^{\text {nd }}\right.$ ed.). London: Sage Publications, Inc.

Dees, J. G. (1998). The meaning of 'social entrepreneurship’. Stanford: Ewing Marion Kauffman Foundation.

Edwards, W. (1954). The theory of decision making. Psychological Bulletins, 51(4), 380417.

Eisenhardt, K. (1989). Building theories from case study research. Academy of Management Review, 14(4), 532-550.

Eisenhardt, K., \& Graebner, M. (2007). Theory building from cases: Opportunities and challenges. Academy of Management Journal, 50(1), 25-32.

Fowler, A. (2000). NGDOS as a moment in history: Beyond aid to social entrepreneurship or civic innovation? Third World Quarterly, 21(4), 637-54.

Hair Jr, J., Black, W., Babin, B., \& Anderson, R. (2018). Multivariate data analysis ( $8^{\text {th }}$ ed.). Essex: Pearson Education.

Howorth, C., Smith, S.M., \& Parkinson, C. (2012). Social learning and social entrepreneurship education. Academy of Management Learning and Education, 11(3), 37189.

Lasrado, V., Sivo, A., Ford, C., O’Neal, R., \& Garibay, I. (2016). Do graduated university incubator firms benefit from their relationship with university incubators?. Journal of Technology Transfer, 41(2), 205-19.

Luc, P.T. (2020). The influence of personality traits on social entrepreneurial intention among owners of civil society organisations in Vietnam. Int. J. Entrepreneurship and Small Business, 40(3), 291-308.

Mas-Verdú, F., Ribeiro-Soriano, D., \& RoigTierno, N. (2015). Firm survival: The role of incubators and business characteristics. Journal of Business Research, 68(4), 79396.

Morgan, D. (1997). Focus groups as qualitative research ( $2^{\text {nd }}$ ed.). London: Sage.

Morgan, D. (2014). The focus group guidebook.London: Sage.

Nga, J. K. H., \& Shamuganathan, G. (2010). The influence of personality traits and demographic factors on social entrepreneurship start up intentions. Journal of Business Ethics, 95, 259-82.

O.Nyumba, T., Wilson, K., Derrick, C.J., \& Mukherjee, N. (2018). The use of focus group discussion methodology: Insights from two decades of application in conservation.Methods in Ecology and Evolution, 9(1), 20-32.

Pache, A., \& Chowdhury, I. (2012). Social entrepreneurs as institutionally embedded entrepreneurs: Toward a new model of social 
entrepreneurship education.Academy of Management Learning and Education, 11(3), 494-510.

Prabhu, G. N. (1999). Social entrepreneurial leadership. Career Development International, 4(3), 40-45.

Rabiee, F. (2004). Focus-group interview and data analysis. Proceedings of the Nutrition Society, 63(4), 655-60.

Ristekdikti. (2017). Buku panduan inkubasi bisnis teknologi 2017.Retrieved from https://ristekdikti.go.id/wpcontent/uploads/2017/03/ACFrOgDjvOcoV m_3eiqb8qXuy4wSFvaYxZ9CxVNImvRQI 1Np_S0lue8NfZxk3NNKv5qqGikVqV08K 1cKXqyPS4ubFD-

MqVExtqAB4iEDaOvjqgKz0lw5B2ODyCu XkN4.pdf.

Robeyns, I. (2005). The capability approach: A theoretical survey. Journal of Human Development, 6(1), 93-117.

Robeyns, I. (2006). The capability approach in practice. Journal of Political Philosophy, 14(3), 351-376.

Robeyns, I. (2017).Wellbeing, freedom, and social justice: The capability approach reexamined. Cambridge: UK Open Book Publishers.

Salamzadeh, A., Azimi, M.A., \& Kirby, D.A. (2013). Social entrepreneurship education in higher education: Insights from a developing country. Int. J. Entrepreneurship and Small Business, 20(1), 17-34.

Schoemaker, P.J.H. (1982). The expected utility model: Its variants, purposes, evident, and limitations. Journal of Economic Literature, 20(2), 529-563.

Sen, A. (1977). Rational fools: A critique of the behavioral foundations of economic theory. Philosophy and Public Affairs, 6, 317-344.

Sen, A. (1985). Well-being, agency, and freedom. The Journal of Philosophy, 82(4), 169-221.

Sen, A. (1990). More than 100 million women are missing by Amartya Sen. New York, NY: The New York Review of Books.
Sen, A. (1992).Functionings and capability: Inequality reexamined. Oxford: Clerendon Press.

Sen, A. (1999). Development as freedom: Development as freedom. New York, NY: Knopf.

Shaw, E., \& Carter, S. (2007). Social entrepreneurship: Theoretical antecedents and empirical analyses of entrepreneurial processes and outcomes. Journal of Small Business and Enterprise Development, 14(3), 418-34.

Sinthupundaja, J., Kohda, Y., \& Chiadamrong, N. (2020). Examining capabilities of social entrepreneurship for shared value creation. Journal of Social Entrepreneurship, 11(1), $1-22$.

Stake, R.E. (2000). Case studies. In I.K. Denzin \& Y.S. Lincoln (Eds.). Handbook of qualitative research ( $2^{\text {nd }}$ ed., pp. 443-466). Thousand Oaks, CA: Sage Publications.

UNDP. (2017).Women's entrepreneurship and access to finance: Challenges and opportunities of women-led social enterprises in Indonesia. Retrieved from https://www.id.undp.org/content/dam/indon esia/2017/doc/INS-Gender Report Revisi.pdf.

Urban, B. (2008). Social entrepreneurship in South Africa. International Journal of Entrepreneurial Behavior \& Research, 14(5), 346-64.

Voisey, P., Gornall, L., Jones, P., \& Thomas, B. (2006). The measurement of success in a business incubation project. Journal of Small Business and Enterprise Development, 13(3), 454-68.

Weaver, R.L. (2018). Re-conceptualizing social value: Applying the capability approach in social enterprise research. Journal of Social Entrepreneurship, 9(2), 79-93.

Yin, R. K. (2003). Applications of case study research $\left(2^{\text {nd }} e d.\right)$. Thousand Oaks, CA:Sage.

Yin, R. K. (2009). Case study research: Design and methods ( $4^{\text {th }}$ ed.). London: Sage. 